\title{
Escutas na imagem e realce do grotesco pelo sublime em Laranja Mecânica
}

\section{Image listening and enhancement of the grotesque in $\boldsymbol{A}$ Clockwork Orange}

\author{
Wander Lourenço da Silva'; Miguel Luiz Contani ${ }^{2}$
}

\section{Resumo}

\begin{abstract}
Este artigo analisa o resultado estético da relação entre os elementos imagéticos e sonoros do filme Laranja Mecânica, de Stanley Kubrick. A fundamentação teórica provém dos conceitos das categorias estéticas tratadas por Sánches Vázquez, do conceito de feio de Umberto Eco, das categorias de sons e dos modos de escuta contemplados na Teoria Cinematográfica de Produção Sonora (Film Sound) proposta por Michel Chion, e das formulações da estética à luz da semiótica de C. S. Peirce. Conclui-se que o código sonoro contribui para realçar a ambiguidade presente na maior parte do filme, sobretudo nos momentos de aplicação da violência de estado e de sistema. Analisando algumas cenas segundo as escutas reduzida, causal, e semântica, pode-se afirmar que a música, ao agregar à cena elementos estéticos contrastantes aos imagéticos, produz uma sensação de realce do grotesco pela mistura de prazer e horror e, por vezes, pela presença do cômico.
\end{abstract}

Palavras-chave: Estética. Semiótica. Audiovisual. Comunicação.

\begin{abstract}
This article examines the aesthetic result from the relation between images and sound elements of the film A Clockwork Orange by Stanley Kubrick. The theoretical framework comes from the concepts of aesthetic categories treated by Sánches Vázquez, the concept of ugly by Umberto Eco, the categories of sound and listening modes included in the Theory of Production Film Sound (Film Sound) proposed by Michel Chion, and formulations of aesthetics in the light of semiotics of C. S. Peirce. It is concluded that the sound code helps to highlight the ambiguity present in most of the film, especially in times of application of state and system violence. Analyzing some scenes according to the wiretaps reduced, causal, and semantics, it could be said that music, by adding elements to the scene to contrasting aesthetic imagery, produces a sense of the grotesque highlight the mixture of pleasure and horror, and sometimes by comic presence.
\end{abstract}

Keywords: Aesthetics. Semiotics. Audiovisual. Communication.

${ }^{1}$ Mestre em Comunicação pela Universidade Estadual de Londrina. Docente da Universidade Estadual de Londrina. Email: wanderlourenco@hotmail.com.

${ }^{2}$ Doutor em Comunicação e Semiótica pela PUC/SP. Docente do Curso de Mestrado em Comunicação da Universidade Estadual de Londrina. Email: contani@sercomtel.com.br. 


\section{Introdução}

Quando nos deparamos com um material ou fenômeno audiovisual, dois de nossos sentidos entram em ação: estamos suscetíveis ao que se vê e ao que se ouve de forma simultânea. Esses dois tipos de linguagem, a visual e a sonora, complementam-se e intercambiam-se, produzindo outra camada de sentido e uma linguagem híbrida. O som sobre a imagem pode agregar significado ou até mesmo alterar substancialmente o caráter desta última, além de provocar experiências sinestésicas. Podemos pensar o material audiovisual nessas camadas de sentido emergidas, resultando sempre um tipo de linguagem não verbal, um fenômeno estético que, por conter uma linguagem múltipla, está suscetível a certas ambiguidades que podem ser usadas propositalmente, a fim de causar um determinado efeito.

Do ponto de vista metodológico, a conceituação semiótica vem como ferramenta de apoio para análise da configuração verbal e não verbal que se forma, e opera do mesmo modo em relação aos elementos de visualidade proveniente de outros tipos de linguagem: pintura, música, cinema, arquitetura, etc. Teorias estéticas surgiram em todas as correntes da semiótica devido ao fato de os signos artísticos exercerem uma grande atração sobre os estudos da linguagem, na medida em que são eficazes para testar a eficiência dos conceitos. Diferentemente de muitas teorias do estético, que restringem o foco apenas na experiência estética, a semiótica fornece elementos teóricos para refletir sobre muitas outras características do estético, misturando sentimento e razão (SANTAELLA, 1994).

Em Laranja Mecânica (1971), de Stanley Kubrick, há diversas experiências sinestésicas (termo que significa evocação de sensações, memórias e sentimentos, a partir de um dado estímulo: cor, imagem, som e outros elementos hibridizados) em que imagens grotescas de violência e obscenidades são acompanhadas por obras musicais reconhecidas como belas, pela sua estruturação harmônico-melódica, por seu histórico de utilização e pelos fatores extramusicais que envolvem sua criação. Serão aqui analisados alguns momentos em que ressaltam esses contrastes e refletir como a ambiguidade entre o sonoro e o imagético culmina num sentido diverso, exercendo, essa mesma ambiguidade, uma função particular ao ser usada como ferramenta na produção do material fílmico.

Como procedimento, procuraremos decompor o material em imagético e sonoro, analisá-los separadamente, e relacioná-los entre si, pois, é nessa instância que se projeta o resultado estético e comunicacional do material audiovisual. A análise apontará os três tipos de escuta propostas por Michel Chion, causal, semântica e reduzida, relacionadas, neste estudo, às categorias de análise dos signos de C.S. Peirce. Para analisarmos o conteúdo imagético das cenas, bem como o resultado estético dessa combinação entre o sonoro e o visual, teremos como apoio, as noções de cômico e grotesco no tratado sobre a feiura, de Umberto Eco, e as categorias estéticas de Sánches Vázquez.

De início, a questão da simbiose entre imagem e som será abordada fazendo referência ao modo com que permeia, não só a história do cinema, como também toda a história do homem. Passaremos, em seguida, aos tipos de sons e de escutas contempladas na Teoria Cinematográfica de Produção Sonora de Michel Chion, descrevendo, nessa abordagem, a articulação e as correlações que podem ser efetuadas com a teoria dos interpretantes de C. S. Peirce. O tópico seguinte discute as categorias estéticas tratadas, tendo como apoio as fundamentações de Umberto Eco e Sánches Vásquez. As análises das cenas escolhidas do filme Laranja Mecânica são acompanhadas da abordagem da questão do realce do grotesco pelo sublime e das conclusões finais, com proposição de questões para estudos futuros. 


\section{Componentes Semióticas das Escutas de Imagem}

Temos como primeiros registros históricos que contêm alguma referência à associação som/ imagem, os de origem religiosa, que tratavam de unir, num mesmo acontecimento, eventos visuais (ritos, encenações) com música ou sons (mantras, textos sagrados). Conforme Salles (2002, p. 8), esses rituais antigos provavelmente foram os precursores, num sentido prático, da formação do paradigma som/imagem. Ainda para Salles (2002), são descritos exemplos desta simbiose em textos tão antigos como o Exxodo bíblico, a Teogonia de Hesíodo ou a Poética de Aristóteles, todos eles relatando, de alguma forma, aspectos de criação oriundos de uma interação entre som e imagem.

No cinema, o som sempre esteve presente, e mesmo antes do advento da tecnologia que viabilizava a sincronização da música com a película. Quando os filmes ainda eram "mudos"(silent movies), a música já estava presente, executada por músicos simultaneamente à exibição do filme. Temos, então, na música, um elemento que pode agregar significado ou até mesmo mudar substancialmente o caráter de uma cena, sendo que tal fenômeno, no entanto, não seria possível se nosso ouvido musical não estivesse acostumado a certo repertório musical ocidental, ou seja, se já não tivéssemos sido treinados a "captar sons e remeter a compreensões previamente estabelecidas no nosso código cultural, o que nos permite ouvir certa sonoridade e relacioná-la ao suspense, ou a dor, ou mesmo uma situação de aventura, entre outras tantas possibilidades" (ALMEIDA, 2007, p. 4).

Chion (1994, p. 144) estabelece uma analogia com o cinema afirmando que, se a imagem é projetada, o som é o "projetor", no sentido de que ele projeta significados e valores às imagens. $\mathrm{O}$ som funciona como elemento de manipulação emocional e semântica dos signos visuais. Por um lado, afetanos diretamente, assim como sons de respiração em um filme podem afetar nossa própria respiração, por exemplo. Temos o viés sonoro utilizado amplamente no cinema, das mais variadas e para os mais variados fins, podendo assim se destacar três tipos de aplicações do som em sua inter-relação com o imagético: imersão, interação, e conceituação.

Segundo Shum (2008), a imersão costuma estar associada a "atmosferas", "climas", emoções e impressões, e se consolida pela, algumas vezes vaga e imprecisa, associação subjetiva entre sons e imagens. Podemos ter como exemplos desta aplicação os sons não diegéticos (cuja fonte sonora não está presente na cena), como a música incidental que é sobreposta à narrativa para criar "climas" como suspense, impacto, etc.

$\mathrm{Na}$ interação o som assume um caráter fortemente indicial, como o toque de uma campainha indica que há alguém que aguarda à porta. Na conceituação, o som é utilizado para criar ou fixar conceitos, formulações e avaliações. É o tipo de som que está ligado particularmente a algo, a alguém ou a alguma ideia, como um hino de um país, uma música fúnebre ou o leitmotiv de um personagem, como o tema que Bernard Hermmann criou para o assassino do filme Psicose de Alfred Hitchcock, que denuncia a presença do mesmo antes que sua imagem apareça em cena.

Como auxílio para análise dos diversos tipos de sons e suas relações com a imagem a que está vinculada em um material audiovisual, bem como seus graus de independência ou dependência em relação às suas fontes sonoras, Shum (2008) cita o modelo de análise proposto por Chion (1994, p. 25-34) que apresenta uma correspondência muito evidente com as categorias peirceanas. Os três modos de escuta: a escuta causal (secundidade), a escuta semântica (terceiridade) e a escuta reduzida (primeiridade). Assim, “a contemplação estética se dá na mistura das três categorias, envolvendo elementos próprios ao sentir (primeiridade), o esforço interpretativo implícito na observação do objeto (secundidade), e na promessa de compreensão e assentimento intelectivo com que esse objeto nos acena (terceiridade)" (SANTAELLA, 1994, p. 183) 
Escuta causal é aquela cujo interesse está na identificação da origem de determinado som, que no material audiovisual está vinculado aos sons de interação. Este modo de escuta é muito útil na sonoplastia principalmente quando a fonte sonora não está presente na tela, funcionando como índice de materialidade e trazendo pistas das condições e características desta mesma fonte.

A escuta semântica está vinculada ao aspecto simbólico, ao conteúdo extrassonoro, de qualquer outro código, que está vinculado ao som. O significado implícito no som pode ser convencionado, como no código Morse em que a duração e repetição dos sons estão ligados aos fonemas ou nos sinais de alerta do computador, ou aprendidos culturalmente, como o hino de um país carrega um caráter patriótico ou um canto gregoriano possui caráter religioso. Este modo de escuta está ligado aos sons de conceituação.

$\mathrm{Na}$ escuta reduzida, o foco do som está em si mesmo, pelas suas características fisiológicas, independentemente de causas ou significados. Neste caso, o som é o objeto de estudo ao invés de ser um veículo para qualquer outra coisa como nos aponta Shum (2008). Os sons de imersão são percebidos nesta categoria de escuta, pois cada som, com suas características físicas, pode nos causar determinadas sensações sem que necessariamente nos remetamos a elementos extrassonoros. Contudo, o que ocorre quando nos deparamos com um fenômeno audiovisual é uma mescla dessas categorias de sons e escutas na maioria das vezes impossíveis de serem separadas duramente. "Como produtores de áudio para filmes, vídeos, hipermídias ou games, podemos estabelecer graus diversos em que os sons estejam mais ou menos vinculados a cada um dos três modos de escuta (causal, semântica e reduzida)" (SHUM, 2008, p. 1138).

Relacionando os três modos de escuta com a Teoria dos Interpretantes de C. S. Peirce, podemos afirmar que quando ocorre a escuta causal, que está vinculada à secundidade e logo aos sons de interação que vinculam o som à sua fonte sonora, o resultado é um interpretante energético - ligado propriamente à existência do fenômeno. Quando ocorre a escuta semântica, que está vinculada à terceiridade e aos sons de conceituação, o resultado é um interpretante lógico, que está ligado ao simbólico. Quando ocorre a escuta reduzida, vinculada à primeiridade e aos sons de imersão, o resultado é um interpretante emocional, que está ligado aos sentimentos e sensações. Porém, Santaella (1994, p. 183), nos adverte que o mais importante na semiótica como meio de compreensão do estético não está apenas na variedade de interpretantes, mas no exame das classes e nas misturas sígnicas que elas permitem:

[...] a teoria dos interpretantes de Peirce nos fornece elementos para perceber que, muito embora o signo possa apresentar potencial para o advento de processos interpretativos multifacetados, densos e complexos, isso não significa que esses processos tenham de realmente se efetivar quando o signo atinge o receptor. Ao contrário, dependendo do receptor, o interpretante pode muito bem estacionar no nível puro e simples de uma qualidade de sentimento, se que o receptor seja levado à uma atividade mais combativa de realização de um esforço interpretativo, tendo em vista responder ao aceno intelectivo do signo. (SANTAELLA, 1994, p. 183).

Quando se ouve música, por exemplo, o interpretante pode perfeitamente permanecer no nível de um sentimento indeterminado, enquanto que receptores mais especializados podem ir além, chegando a uma compreensão intelectual do objeto.

\section{A Estética na Obra Cinematográfica - O Grotesco, o Cômico e o Obsceno.}

A estética, reconhecida desde Platão como a filosofia do belo, trata também de categorias que poderiam ser ditas como opostas desse elemento central, o feio, o grotesco, o cômico e o obsceno. Historicamente, segundo Sánches Vázquez (1999, p. 286), o grotesco aparece vez por outra na literatura e na arte com Rafael, El Bosco e Pieter Bruegel, na Commedia dell'Arte na Itália, nas gravuras de Jacques Callot, nas comédias de Molière, na novela pré-romântica de Sterne, em 
Vida e opiniões de Tristam Shandy, no Gargantua e Pantagruel de Rebelais na pintura negra e as águasfortes de Goya e, para se encarnar finalmente, de um modo exemplar e já mais perto de nosso tempo, nos contos de Hoffmann, Edgar Allan Poe e Gogol. Em nosso século, o grotesco aparece em Kafka, na pintura surrealista de Salvador Dali e nas gravuras de Kubin.

O grotesco manifesta-se no romantismo como um modo de fazer arte que não busca a produção do belo. Em nossa época, destacam-se o tratado sistemático de Wolfgang Kaiser e o estudo de Baktin sobre o grotesco de Rabelais, e sua vinculação com a cultura popular medieval. A categoria estética do grotesco nunca contou com a aprovação da estética clássica, esta que fazia girar o universo estético em torno do belo.

[...] embora sempre sob condenação dessa estética classicista, o grotesco ocorre em uma ampla prática artística que extrai de uma pintura ornamental romana descoberta no final do século XV, denominada grottesca, derivada do substantivo italiano grotta (gruta). Tratava-se de um conjunto de formas vegetais, animais e humanas que se combinam de um modo insólito e fantástico. (SÁNCHES VÁZQUEZ, 1999, p. 285).

O grotesco hoje está frequentemente ligado a outras esferas da estética como, dentre as aqui citadas, o cômico e o obsceno. Para Sánches Vázquez (1999, p. 272), o cômico é uma forma de crítica social, "enquanto que a ordem estabelecida se ampara na seriedade e solenidade para se legitimar, o riso mina seus alicerces". Rir é uma forma de liberdade. Não se pode rir à força. $O$ riso é socialmente subversivo e irrita a censura das sociedades fechadas e autoritárias com a comicidade que suscita. A sátira, pode-se dizer, é a mais agressiva categoria do cômico, pois revela não só a inconsistência do objeto satirizado, mas também sua negatividade, razão pela qual os golpes que descarrega sobre ele buscam a sua destruição. Para Sánches Vázquez (1999, p. 279), entramos na esfera da sátira quando o objeto ou fenômeno revela sua inconsistência ou nulidade a ponto de deixar que se perca toda sua simpatia e o riso já não é mais terno, porém bem mais por indignação ou ira: a desvalorização é tão radical que nos leva a conclusão de que o objeto não merece subisistir.

O obsceno, por sua vez, pelo menos na sociedade ocidental, causa repulsa no ser humano que se mostra incomodado com tudo o que é excrementício ou é ligado ao sexo. Se por um lado, na Grécia Clássica e no Renascimento, os atributos sexuais eram exibidos para tornar mais evidente a beleza de um corpo, e isso era feito sem constrangimentos, nas sociedades onde existe um forte senso de pudor, o gosto por sua violação manifesta-se através do que seria contrário ao pudor, a obscenidade, como afirma Eco (2007, p. 132). Podem-se exibir comportamentos obscenos por raiva ou provocação, mas de uma maneira geral, comportamentos obscenos estão ligados também ao humor, visto que até mesmo crianças apreciam piadas sobre excrementos.

É reconhecido que certos padrões estéticos estão sujeitos ao repertório perceptivo de cada época e cultura, porém, existem elementos que, conforme a história nos mostra, apesar das variáveis de tolerância ou de impacto, de certa forma, parecem manter seu caráter como uma entidade autônoma, com sua identidade determinada essencialmente pela sua fisiologia. É o caso do diabolus in musica abordado por Eco (2007):

O ouvido dos antigos percebia como dissonantes
certos intervalos musicais, julgando-os desagradáveis,
e, durante séculos, o caso clássico de feio musical foi
o intervalo de quarta aumentada, ou excedente, como,
por exemplo, dó-fá sustenido. Na idade média, esta
dissonância era tão perturbadora que foi definida
como diabolus in musica. Contudo, psicólogos
revelaram que as dissonâncias têm um poder excitante
e muitos musicistas, desde o século XIII, empregavam-
nas para produzir determinados efeitos em contextos
apropriados. (ECO, 2007, p. 421).

O diabolus serviu para produzir efeitos de tensão que esperam por uma solução, e foi usado por Bach, Mozart, Lizst, Moussorgsky, Sibelius, Puccini na Tosca e até em West Side Story, de Bernstein, ou mesmo e com frequência, para sugerir aparições 
infernais, em Berlioz, na Danação de Fausto. O caso do diabolus in musica nos inspira algumas reflexões. Para Eco (2007, p. 421), a questão do que é feio e/ ou aceitável é relativa aos tempos e culturas: o que é percebido como feio pode vir a contribuir para a beleza do conjunto. No entanto, como correção dessa perspectiva relativista, podemos dizer que, se é percebido que o diabolus sempre foi empregado para criar tensão, então existem reações baseadas em nossa fisiologia que permanecem mais ou menos inalteradas através dos tempos e das culturas. "Pouco a pouco, o diabolus foi aceito, não porque tinha se tornado agradável, mas justamente por causa do cheiro de enxofre que nunca perdeu" (ECO, 2007, p. 421).

\section{Laranja Mecânica e a Recorrência da Ambiguidade na Violência}

Em 1971, Stanley Kubrick (1955-1999), um dos notáveis cineastas de todos os tempos, lançara o filme Laranja Mecânica (A Clockwork Orange), adaptação do romance homônimo de 1962 do escritor inglês Anthony Burgess. O ator Malcolm McDowell interpreta Alex, o protagonista. O filme é ambientado numa Inglaterra do futuro, em um indeterminado, e mostra a vida de um jovem cujos gostos vão dos mais refinados aos mais truculentos, variando da música suprema de Beethoven à prática de delitos como estupro, vandalismos e espancamentos. Alex é líder de uma gang de arruaceiros aos quais se refere como "druguis" (palavra originária do russo Drug - Друг; amigo). Alex narra a maioria do filme em "Nadsat", um idioma que mistura o russo, o inglês e o cockney.

Alex é traído por seus amigos e capturado durante um assalto, em que a vítima do roubo morreu, e é sentenciado e é sentenciado a 14 anos de prisão. Após ter cumprido dois anos de prisão, ele é liberado na condição de se submeter ao tratamento Ludovico, uma terapia experimental de aversão, desenvolvida pelo governo como estratégia para deter o crime na sociedade. O tratamento consiste em, preso por uma camisa de força, um imobilizador para a cabeça e ganchos que mantém seus olhos abertos, assistir a repetidas sessões de filmes que contêm formas extremas de violência. Também é drogado para que associe as ações violentas com a dor que estas lhe provocam. O tratamento o torna incapaz de qualquer ato de violência, bem como de tocar uma mulher nua. Como efeito secundário, também não consegue ouvir a Nona Sinfonia de Beethoven, sua peça favorita.

Sem a capacidade de se defender, e por ter sido desalojado por seus pais, Alex deprimido, sentindose abandonado e desamparado, perambula pelas ruas de Londres e, após mais algumas desventuras, chega à casa do escritor cuja esposa havia estuprado. O escritor o deixa entrar antes de descobrir sua identidade. Logo, droga Alex e o leva a uma tentativa de suicídio ao fazê-lo ouvir incessantemente uma versão eletrônica da Nona Sinfonia de Beethoven. Alex se joga de uma janela, mas sobrevive.

Depois de uma intensiva recuperação no hospital, Alex parece ser o de antes. No hospital, o Ministro do Interior (que havia antes selecionado Alex pessoalmente para o tratamento Ludovico) visita Alex, desculpando-se pelos efeitos do tratamento. Antecipando seu regresso, Alex narra o final do filme: "Definitivamente, estava curado", enquanto se vê uma fantasia surreal dele mesmo mantendo relações com uma mulher na neve, rodeado por damas e cavaleiros vitorianos aplaudindo, e pode-se escutar o último movimento da Nona Sinfonia ao fundo.

São várias as cenas do filme em que se dá por presente a ambiguidade entre o sublime e o grotesco. As misturas entre o belo, o obsceno, o cômico e o rude hipertrofiam a estética bizarra e surreal do filme. A seguir temos a análise de algumas das cenas em que esses contrastes se encontram mais presentes.

O primeiro choque entre o grotesco e o belo é encontrado no trecho que tem início aos 4':34". É a cena do velho cassino onde ocorre tentativa 
de estupro e briga entre gangues, tudo isso acompanhado a uma bela valsa de Rossini. A cena inicia com o plano de tomada fechado em uma pintura localizada acima do palco do local: nesse momento, as cordas executam as primeiras frases musicais da valsa, e então o plano de tomada vai se abrindo lentamente. A cena até ali poderia ser a de um belo jantar ou de uma festa burguesa qualquer, não fossem os gritos de uma mulher a denunciarem que, naquele local, acontecia uma situação de tensão e perigo. O plano se abre mais a ponto de mostrar todo o palco onde se encontra a gangue de Billyboy tratando de despir uma jovem de suas vestes a fim de violentá-la.

Figura 1 - Luta no Antigo Cassino 1

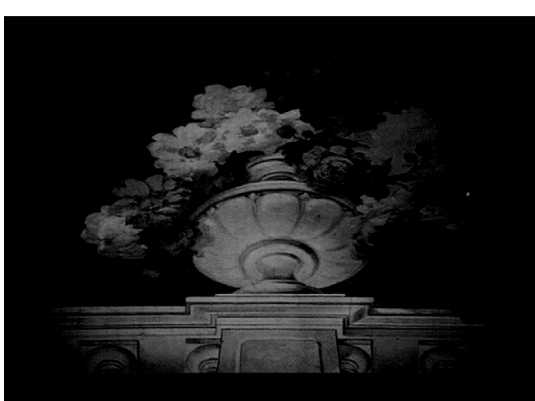

4 ':38"

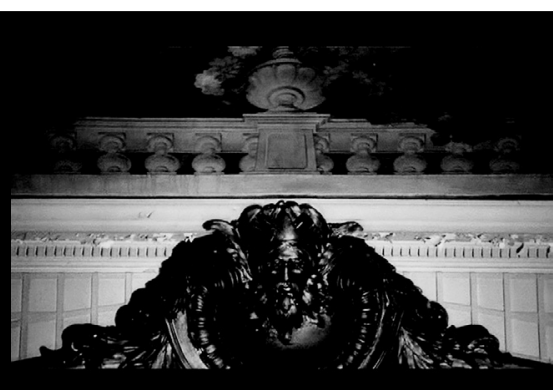

$4^{\prime}: 45^{\prime \prime}$

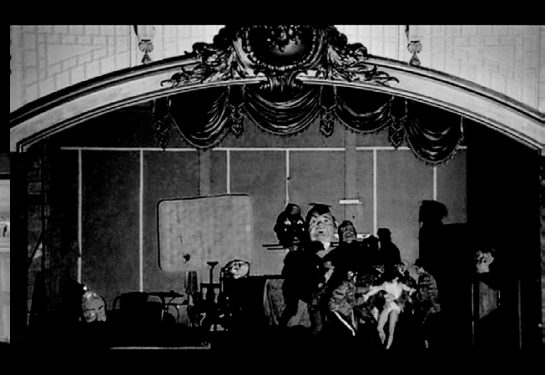

4:57"
Quando a gangue de Alex adentra o local, Billyboy e seus comparsas deixam que a jovem escape, pois, certamente deveriam achar mais divertido uma luta entre gangues rivais. Quando o grupo de Billyboy parte em direção a Alex e seus amigos, a música aumenta de intensidade e a cena de luta segue com profusão de golpes de garrafas, correntes, cadeiras e mesas. Em certos momentos, o resultado chega a conter uma certa comicidade, parecendo fazer referência aos filmes de comédia pastelão. A música fica mais intensa à medida que a luta vai ficando cada vez mais violenta, até que o volume da valsa diminui, e Alex chama atenção para que seus amigos parem de massacrar seus rivais, pois, naquele momento, se ouvia a sirene da polícia.

Figura 2 - Luta no Antigo Cassino 2

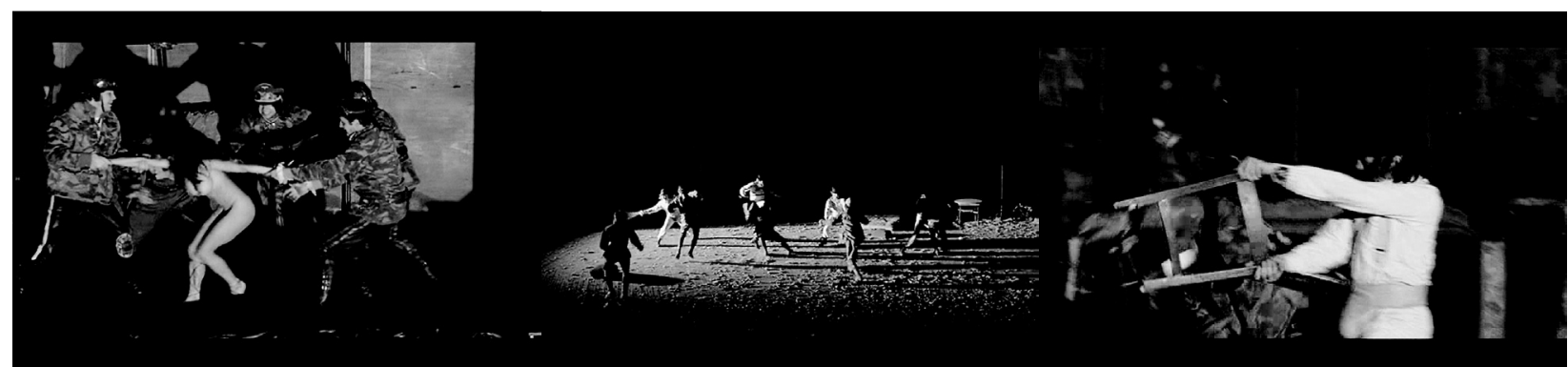

$5^{\prime}: 25^{\prime \prime}$

6':36"

6:42" 
A segunda cena a ser analisada se dá quando Alex e seus amigos chegam à residência de um escritor e de sua esposa. Mentindo sobre a ocorrência de um acidente conseguem adentrar a residência e imediatamente começar a cruel violência contra o casal, tudo acompanhado pelo clássico Singing in the Rain, do filme Cantando na Chuva, interpretado por Gene Kelly. Desta vez a trilha sonora acontece diegéticamente com o próprio Alex cantando a música, com sua bela melodia e alegre letra.

Nos primeiros versos da canção Alex faz com que inclusive suas vítimas participem, quando, ao usar violentos golpes, deixa para que o casal execute aflitamente notas da melodia com seus gritos de dor antes de silenciá-los tapando suas bocas com bolinhas de borracha e fita adesiva. A violência continua com Alex danificando os pertences da casa, espancando o casal e rasgando, com a ajuda de uma tesoura, a roupa da mulher, preparando-a para ser estuprada frente aos olhos de seu marido. Alex tira suas calças e, com sua máscara cujo nariz tem o formato de um órgão genital masculino, aproximase do rosto do escritor que se encontra imobilizado por um de seus comparsas e diz a ele para olhar bem. A cena é cortada.

Figura 3 - Invasão à Residência do Casal

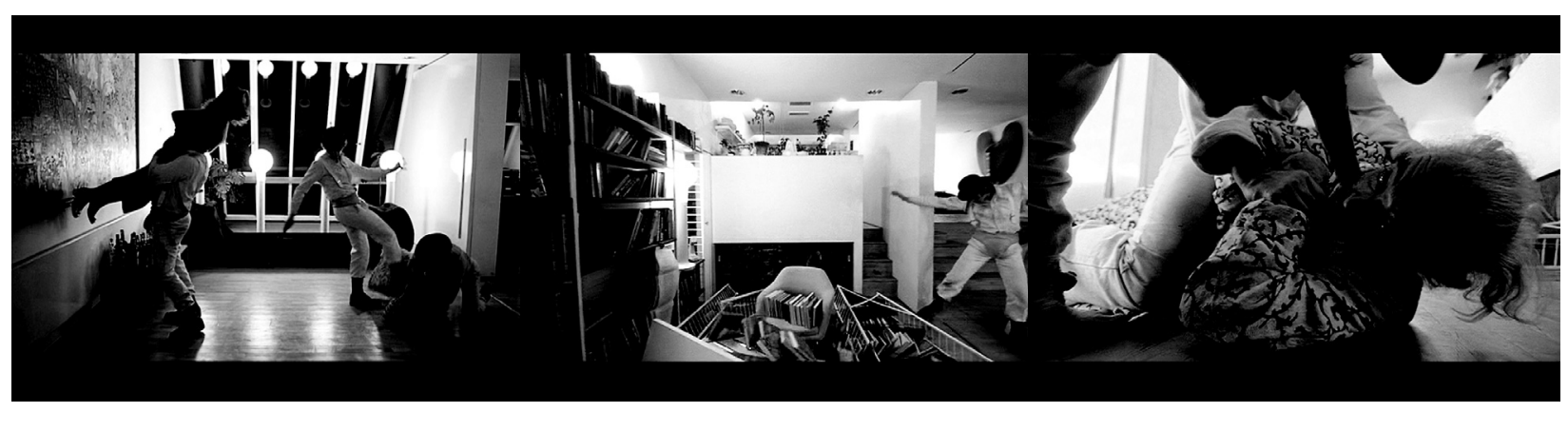

A terceira cena exemplar encontra-se durante o tratamento de Alex. Dentre as muitas sessões de cinema a que é submetido, sempre após ter sido drogado, uma delas tem em seu "cardápio" um filme com conteúdo bélico. O filme contém cenas de bombardeios, destruição, exército nazista, aparições de Hitler, e várias outras atrocidades as quais dificilmente, um ser humano que tem conhecimento do que aquilo significa ficaria inerte ao assistir.

A música que acompanha todas aquelas imagens é uma versão eletrônica do quarto movimento da Nona Sinfonia de Ludwig van Beethoven, a Beethoviana, de Walter Carlos. Neste caso a música faz parte do filme a que Alex assiste, sendo que, a percepção da ambiguidade e a sensação de desconforto provocadas pelo choque estético é possível, não só para quem assiste à cena de Laranja Mecânica, mas também para o protagonista do filme que, nesse momento, entra em pânico implorando para que a sessão seja interrompida por não suportar a obra suprema de seu ídolo sendo utilizada para ambientar, sonoramente, algumas da mais terríveis atrocidades já cometidas pelo homem. 
Figura 4 - O Tratamento de Alex

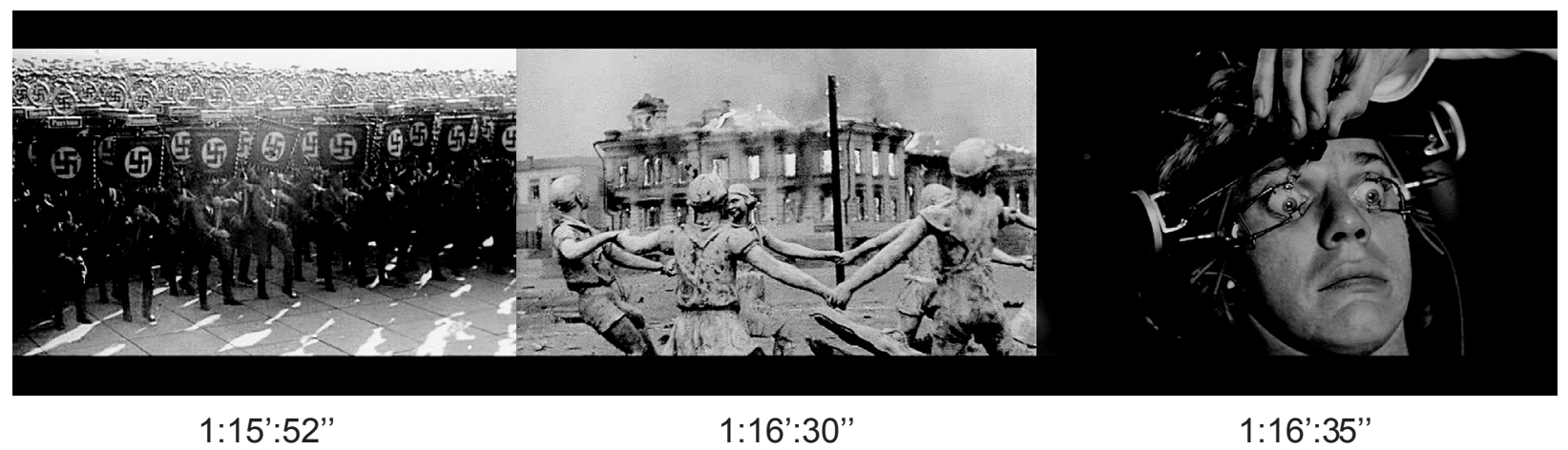

\section{O Realce do Grotesco pelo Refinado - Um Desafio Estético}

A cena do antigo cassino retrata elementos dos mais rudes da natureza humana coexistindo com outros da mais fina arte que sempre almejou o belo em suas obras, como a música dita clássica e a bela decoração do local, que combina pintura e escultura. São percebidos, pela escuta reduzida, gritos e sons de destruição, como pancadas, vidro e madeira se quebrando, além de uma música alegre, de caráter dançante e festivo permeando toda a cena. Pela escuta causal, observamos que a música acontece não diegeticamente, ou seja, é sobreposta à narrativa. Os gritos de horror vêm da jovem que é despida de suas vestes pela gangue de Billyboy que, ao que tudo indica, tem a intenção de violentá-la. As pancadas e sons de garrafas, mesas e cadeiras se quebrando, vêm do confronto entre a gangue de Billyboy e a de Alex, que interrompe a violência contra a jovem a fim de disputarem uma violenta luta.

Pela escuta semântica, podemos concluir que a aqui presente valsa de Rossini, peça musical de caráter dançante que serve amplamente para o deleite de quem aprecie a bela música clássica ocidental, funciona como apoio a outro tipo de dança mais selvagem, a da obscenidade e da violência gratuitas. Em certos momentos, a trilha sonora que faz com que seja gerada certa estranheza pela sua diferença de caráter com o material imagético, confere, à cena, certa comicidade. Mesmo assim, a estética do grotesco não deixa de ser acentuada. Como aponta Sánches Vázquez (1999, p. 276), desde Platão não tem faltado quem considere o cômico a mais vulgar das categorias estéticas.

A cena da invasão à residência do casal combina violência, obscenidade, comicidade e de prazer, o que reforça o caráter grotesco e surreal da situação. Apesar de formarem uma gangue de delinquentes, Alex e seus amigos demonstram uma preocupação estética, com seus uniformes brancos, chapéus, suspensórios e até outros acessórios, como cílios postiços. Nesta cena, Alex faz uso de uma máscara que mais parece uma caricatura, que com certeza tem sua ligação com o grotesco. Eco (2007, p. 152), nos indica que uma das formas do cômico é, sem dúvida, a caricatura. Embora esta seja moderna, alguns assinalam seu início em certos retratos grotescos de Leonardo. A máscara, além de remeter ao grotesco por ser caricata, é carregada da mesma obscenidade do ato que Alex comete, por conta da semelhança de seu nariz hipertrofiado, com o órgão masculino. Desde a antiguidade, o culto ao falo uniu características de obscenidade, feiúra e de certa comicidade, exemplo disso seria a história de Príapo, filho de Afrodite, protetor da fertilidade, dotado de um órgão sexual enorme, conforme Eco (2007, p. 133).

A partir da escuta reduzida, percebemos, na cena, a aparentemente prazerosa execução de uma canção com ritmo dançante, e melodia e letra alegres, acompanhada por risos, gritos e sons de 
golpes. Pela escuta causal, percebemos que Alex está de fato deleitando-se ao cantar a melodia, saltitando e executando passos de sapateado. Os risos de seus comparsas são, de fato, risos satíricos que se dão pela contemplação da dor de outrem, e os gritos das vítimas são de dor e aflição perante aquela situação a que são submetidos. Pela escuta semântica, instância em que tentamos tecer relações simbólicas de sentido e de significado, é possível perceber o reforço do grotesco pela trilha sonora que acontece aqui diegeticamente. $\mathrm{O}$ fato de a cruel prática ser acompanhada por Singing in the Rain, que além de conter elementos estruturais que a caracterizam subjetivamente como uma canção alegre, é conhecida por utilizações anteriores em contextos positivos, agrega à cena sadismo e prazer pelo sofrimento alheio.

$\mathrm{Na}$ acima referida cena da sessão de tratamento de Alex, pela escuta reduzida, percebemos a execução de uma versão do Quarto Movimento da Nona Sinfonia de Beethoven aliada aos pedidos de Alex para que a sessão seja interrompida. Pela escuta causal, podemos dizer que a música acontece diegeticamente para nós expectadores e não diegeticamente para Alex que assiste ao vídeo com conteúdo bélico cuja trilha sonora fora sobreposta posteriormente. Podemos dizer que nesse caso, para nós, a obra de Beethoven tem uma função de conceituação e, para o contexto de Alex, exerce a função de imersão.

Semanticamente, ao nos concentrarmos no filme que é apresentado a Alex, fica nítida a ambiguidade contida. A Nona Sinfonia, que aqui é apresentada em uma versão eletrônica de Walter Carlos, é reconhecida como a primeira sinfonia a contar com vozes, e além de conter elementos estruturais tidos como alegres na cultura ocidental, como tonalidade maior e ritmo movido, tem, como conteúdo lírico, um texto de Schiller chamado Ode à Alegria. O grotesco aqui é novamente acentuado pelo fato de a beleza e a genialidade de um dos maiores artistas de toda a história servirem de apoio às imagens que mostram algumas das piores crueldades e atrocidades que o homem, com todo sua intelectualidade e arrogância, já foi capaz de cometer. Desta vez, tal recurso não é direcionado apenas aos espectadores de Laranja Mecânica, mas também ao seu protagonista que encontra, nesse momento, o mais desesperador de seu tratamento.

\section{Considerações Finais}

O estudo apresentado neste artigo procurou, com emprego de uma metodologia baseada nos tipos e funções do som e dos modos de escuta propostos por Michel Chion articulados às bases semióticas encontrados na teoria dos signos de C. S. Peirce, analisar a relação sonoro-imagética de algumas das cenas do filme Laranja Mecânica. Reforço para essa tarefa foi também buscado nas categorias estéticas contempladas por Sánches Vázquez e Umberto Eco. A inferência que se tornou possível foi a de que a recorrência da utilização de um recurso que, ao unir imagens de natureza do feio e do negativo com sons de natureza do belo e do sublime, tem-se um resultado estético de realce do grotesco, justamente pela sensação bizarra e surreal que tende a passar.

A questão das sensações percebidas frente ao fenômeno estético, bem como a presença de outros elementos subjetivos, fazem-nos remeter rapidamente também à cena em que Alex tem delírios e pensamentos sobre enforcamentos, explosões, soterramentos e ele dele mesmo na figura de um vampiro, acompanhado pelo Segundo Movimento da Nona Sinfonia de Beethoven, ou à cena em que participa de uma orgia com duas garotas em seu quarto, que se dá em imagem acelerada e com o acompanhamento da Abertura de William Tell de Rossini, entre outras.

Concluímos que os elementos metodológicos e conceituais abordados aqui reúnem formas aptas à construção de um ponto de vista a ser utilizado na difícil análise de fenômenos artísticos e não verbais, nesse caso, o de código múltiplo, audiovisual. É importante remontar também às categorizações de 
sons e escutas levantadas e o modo como se tornam potencializadas pelas categorizações da semiótica permitindo maior nitidez para enxergar as constantes sobreposições e inter-relações. Por seu valor de guia analítico, podem enriquecer os meios de realizar a leitura e a compreensão de materiais audiovisuais no que eles oferecem de mais sutil: a evocação.

\section{Referências}

ALMEIDA, I. R. Trilha sonora e implicações significativas no cinema: análise a partir do Filme "1984". In: CONGRESSO BRASILEIRO DE CIÊNCIAS DA COMUNICAÇÃO DA REGIÃO NORTE, 6., 2007, Belém. Anais... Belém: Intecom, 2007.

CHION, M. L. Audio-vision: sound on screen. New York: Columbia University Press, 1994.

ECO, H. História da feiúra. Rio de Janeiro: Record, 2007.

PEIRCE, C. S. Collected papers. Cambridge: Harvard University Press, 1958. p. 1931-1935.

SALLES, F. M. Imagens musicais ou música visual: um estudo sobre as afinidades entre o som e a imagem, baseados no filme Fantasia de W. Disney. 2002. Dissertação (Mestrado em Comunicação e Semiótica) - Pontifícia Universidade Católica de São Paulo, São Paulo.

SÁNCHES VÁZQUEZ, A. Convite à estética. Rio de Janeiro: Civilização Brasileira, 1999.

SANTAELLA, L. Estética de Platão a Peirce. São Paulo: Experimento, 1994.

SHUM, L. R. Funções e aplicações do som na comunicação audiovisual. In: ENCONTRO DA UNIÃO LATINA DE ECONOMIA POLÍTICA DA INFORMAÇÃO, DA COMUNICAÇÃO E DA CULTURA. 2., 2008, Bauru. Anais... Bauru: Unesp, 2008. 
